\title{
KINERJA PELAYANAN BUS TRANS MAMMINASATA DI KORIDOR 3 KAWASAN MAMMINASATA
}

\author{
Qadriathi Dg Bau \\ Jurusan Pendidikan Teknik Sipil dan Perencanaan \\ Universitas Negeri Makassar \\ Jln. Daeng Tata Raya Parang Tambung, Makassar \\ qadriathidgbau@gmail.com
}

\author{
Reza Muhajir \\ Program Pascasarjana \\ Universitas Bosowa \\ Jln. Urip Sumihardjo, Makassar \\ rezamuhajir87@gmail.com
}

\author{
Batara Surya \\ Program Pascasarjana \\ Universitas Bosowa \\ Jln. Urip Sumihardjo, Makassar
}

\begin{abstract}
Bus Rapid Transit is expected to become mass transportation serving the Mamminasata agglomeration area, which includes Makassar City, Maros Regency, Gowa Regency and Takalar Regency. Efforts to realize the South Sulawesi Provincial Government program related to the implementation of the Mamminasata Bus Rapid Transit are very dependent on the services provided. This study aims to analyze the effectiveness of service performance and its effect on the movement system in Corridor 3 of the Mamminasata Region. This research method uses descriptive analysis techniques. The results of this study indicate that several service performance criteria are effective, such as service quality based on travel speed, level of fleet availability, vehicle age, low costs or affordable rates, safety or security and convenience, and timeliness of service based on travel time of each segment and service time. Whereas those that have not been effective include number of buses and fleet capacity, load factor, frequency, distance between stops, operating ratio, regularity, orderliness, accessibility, reliability, easily-accessed information, waiting time, headway, vehicle downtime, travel time, and circulation time.
\end{abstract}

Keywords: Bus Rapid Transit, mass transit, service performance, movement system

\begin{abstract}
Abstrak
Bus Rapid Transit diharapkan menjadi angkutan massal yang melayani wilayah aglomerasi Mamminasata, yang meliputi Kota Makassar, Kabupaten Maros, Kabupaten Gowa, dan Kabupaten Takalar. Upaya mewujudkan program Pemerintah Provinsi Sulawesi Selatan terkait penerapan Bus Rapid Transit Mamminasata ini sangat bergantung pada pelayanan yang diberikan. Penelitian ini bertujuan menganalisis efektivitas kinerja pelayanan dan pengaruhnya terhadap sistem pergerakan di Koridor 3 Kawasan Mamminasata. Metode penelitian ini menggunakan teknik analisis deskriptif. Hasil penelitian ini menunjukkan bahwa beberapa kriteria kinerja pelayanan sudah efektif, seperti kualitas pelayanan berdasarkan kecepatan perjalanan, tingkat ketersediaan armada, umur kendaraan, biaya rendah atau tarif terjangkau, keselamatan atau keamanan dan kenyamanan, serta ketepatan waktu pelayanan berdasarkan waktu tempuh setiap segmen dan waktu pelayanan. Sedangkan yang belum efektif meliputi kapasitas dan jumlah armada, faktor muat, frekuensi, jarak antarhalte, rasio operasi, keteraturan, ketertiban, komprehensif, aksesibilitas, keandalan, kemudahan informasi, waktu tunggu, waktu antara, waktu henti kendaraan, waktu perjalanan, serta waktu sirkulasi.
\end{abstract}

Kata-kata kunci: Bus Rapid Transit, angkutan massal, kinerja pelayanan, sistem pergerakan

\section{PENDAHULUAN}

Kawasan Mamminasata yang terdiri atas Makassar, Maros, Sungguminasa, dan Takalar merupakan daerah aglomerasi. Berdasarkan data Dinas Perhubungan Provinsi 
Sulawesi Selatan tahun 2016, arus pergerakan perjalanan di Kawasan Mamminasata semakin meningkat, dengan jumlah bangkitan dan tarikan perjalanan mencapai 1.625 .720 orang per hari (BPS, 2017). Bus Rapid Transit (BRT) diharapkan menjadi angkutan massal yang melayani wilayah aglomerasi tersebut. BRT yang dikelola oleh pemerintah harus mampu bersaing secara kompetitif dengan bus swasta, sehingga pemerintah harus fokus memperbaiki kinerja dan meningkatkan mutu pelayanan angkutan BRT tersebut.

Persoalan transportasi di Kawasan Mamminasata tidak hanya pada faktor eksternal, namun permasalahan juga dapat terjadi pada internal pemerintahan dalam merumuskan kebijakan yang tidak diimbangi dengan implementasinya, untuk menjalankan program yang sudah ditetapkan. Penyebab tidak tercapainya tingkat keberhasilan implementasi yang baik ternyata dipengaruhi oleh 5 faktor, yaitu kurangnya koordinasi antarlembaga, jumlah staf atau personel yang belum memadai, minimnya pendanaan dan peralatan, rendahnya kesadaran masyarakat, dan kemudahan akses kepemilikan kendaraan pribadi.

Upaya mewujudkan keberhasilan program pemerintah terkait penerapan BRT Trans Mamminasata sangat bergantung pada pelayanan yang diberikan. Dimensi pelayanan tersebut meliputi ekonomis, efisiensi, efektivitas, dan keadilan yang diberikan, sedangkan kebijakan transportasi merupakan salah satu tindakan yang diambil pemerintah dalam menangani dan memecahkan segala pemasalahan yang terjadi di sektor transportasi, namun memperhatikan segala aspeknya. Menurut Warpani (2002), kinerja angkutan umum merupakan hasil kerja angkutan umum yang beroperasi untuk melayani segala kegiatan masyarakat dalam berpergian maupun beraktivitas. Adapun parameter atau indikator untuk mengukur tingkat keberhasilan sistem operasi yang digunakan, antara lain load factor, waktu antara (headway), waktu henti kendaraan, waktu tempuh setiap halte, waktu perjalanan, kecepatan perjalanan, waktu sirkulasi, frekuensi, jarak antarhalte, availability, waktu pelayanan, umur kendaraan, operation ratio, dan kapasitas.

Wilayah penelitian ini berfokus pada Koridor 3 BRT Trans Mamminasata, yang merupakan ruas jalan penghubung antara Kota Maros, Sungguminasa, dan Takalar. Rute yang dilayani oleh bus Trans Mamminasata berawal dari simpang lima Bandara Sultan Hasanuddin, Jln. Perintis Kemerdekaan, Jln. Urip Sumoharjo, Jalan A.P. Pettarani, Jln. Boulevard-Mall Panakukang, Jln. A.P. Pettarani, Jln. S. Alauddin, Jln. Poros Gowa, dan Terminal Palangga Sungguminasa, pulang pergi.

Populasi pada penelitian ini adalah jumlah penumpang pada Koridor 3, yaitu sebanyak 546 penumpang per hari, dengan rata-rata jumlah bus yang beroperasi sebanyak 7 unit. Berdasarkan rumus Isaac dan Michael diperoleh ukuran sampel yang digunakan sebanyak 82 penumpang (Sugiyono, 2014). Namun, untuk memaksimalkan data pada perjalanan bus pulang pergi, ukuran sampel yang digunakan adalah sebanyak 100 penumpang, dengan tingkat kesalahan 5\% dan perbedaan antara rata-rata sampel dengan rata-rata populasinya adalah $10 \%$.

Pengumpulan data pada penelitian ini dilakukan melalui observasi, survei, wawancara terbuka dan tertutup, serta dokumentasi. Rincian pelaksanaannya adalah sebagai berikut: 
1) Observasi; merupakan pengamatan untuk mendapatkan gambaran kinerja operasi bus Trans Mamminasata di Koridor 3.

2) Survei; meliputi: (a) survei lapangan, untuk mengukur waktu tempuh setiap halte berdasarkan jarak dan kecepatan perjalanan, (b) survei statis, yang dilakukan di luar kendaraan dengan maksud mengamati jumlah armada yang beroperasi, frekuensi pelayanan, waktu pelayanan, dan waktu antarkendaraan, (c) survei dinamis, untuk mengamati jam keberangkatan dan jam kedatangan bus, pergerakan naik turunnya penumpang di setiap halte, waktu perjalanan, waktu tempuh di setiap halte, waktu sirkulasi, waktu henti pada halte, serta waktu pelayanan bus.

3) Wawancara terbuka dan wawancara tertutup dengan maksud untuk mengetahui kinerja pelayanan menurut persepsi pengguna yang terkait dengan keselamatan atau keamanan, waktu tunggu, komprehensif, biaya, kenyamanan, aksesbilitas, keandalan, dan kemudahan informasi. Data yang diperoleh bersifat kuantitatif atau dapat diukur dan dianalisis secara statistika.

4) Dokumentasi dimaksudkan untuk mendapatkan dokumen yang berasal dari instansi atau dinas-dinas terkait maupun dari literatur-literatur yang berkaitan dengan penelitian ini.

Teknik analisis data yang digunakan dalam penelitian adalah teknik analisis statistika deskriptif. Teknik analisis ini digunakan untuk mendeskripsikan atau merangkum data yang telah terkumpul sebagaimana adanya tanpa bermaksud membuat kesimpulan yang berlaku umum atau generalisasi. Penilaian kinerja operasional dan kinerja pelayanan bus Trans Mamminasata di Koridor 3 menggunakan skala Likert, dengan kategori efektif (3), cukup efektif (2), dan kurang efektif (1). Kinerja operasional sendiri dinilai berdasarkan standar atau ketentuan Direktorat Jenderal Perhubungan Darat tahun 1996 (Abubakar, 1996), World Bank tahun 1986 (Armstrong-Wright dan Thiriez, 1987), Konsep Standardisasi Sarana dan Prasarana BRT (Kemenhub, 2012). Sedangkan kinerja pelayanan dikembangkan menggunakan skor ideal atau kriterium untuk mendapatkan gambaran persentase yang dihasilkan dari yang diharapkan, yaitu $100 \%$.

\section{HASIL DAN PEMBAHASAN}

\section{Faktor Muat}

Data faktor muat (load factor) diperoleh dari hasil survei dinamis yang dilakukan di dalam bus. Survei ini dimaksudkan untuk mengetahui jumlah penumpang dengan kapasitas bus. Hasil survei disajikan pada Tabel 1.

Pada Tabel 1 terlihat bahwa nilai faktor muat tertinggi terjadi pada hari Minggu, yaitu $20 \%$ dan faktor muat terendah terjadi pada hari Senin, yaitu sebesar $14 \%$. Nilai ratarata faktor muat adalah 16\%, yang berarti bahwa kinerja BRT kurang efektif. Penyebab hal ini adalah minimnya jumlah penumpang. 
Tabel 1 Faktor Muat

\begin{tabular}{lccc}
\hline \multirow{2}{*}{ Waktu Pelayanan } & \multicolumn{3}{c}{ Hari } \\
\cline { 2 - 4 } & Kamis & Minggu & Senin \\
\hline 06:00-08:00 & 16 & 1 & 14 \\
08:00-12:00 & 33 & 49 & 23 \\
12:00-14:00 & 11 & 9 & 18 \\
14:00-16:00 & 9 & 24 & 14 \\
16:00-18:00 & 21 & 32 & 19 \\
Jumlah penumpang & 90 & 115 & 88 \\
Jumlah rit & 6 & 6 & 6 \\
Kapasitas bus & 95 & 96 & 108 \\
\hline Faktor muat & $16 \%$ & $20 \%$ & $14 \%$ \\
\hline
\end{tabular}

\section{Waktu Antarkendaraan}

Data waktu antarkendaraan didapatkan dari hasil survei statis pada halte. Hasil survei ini disajikan pada Tabel 2.

Tabel 2 Waktu Antarkendaraan (menit)

\begin{tabular}{lccccc}
\hline Hari & Mtos & Unismuh & $\begin{array}{c}\text { Badan } \\
\text { Arsip }\end{array}$ & $\begin{array}{c}\text { Depan } \\
\text { Mtos }\end{array}$ & Rata-Rata \\
\hline Sabtu & $0: 42$ & $0: 45$ & $0: 43$ & $0: 44$ & $0: 43$ \\
Minggu & $0: 45$ & $0: 50$ & $0: 48$ & $0: 47$ & $0: 48$ \\
Rabu & $0: 37$ & $0: 38$ & $0: 42$ & $0: 46$ & $0: 41$ \\
Jumat & $0: 46$ & $0: 53$ & $0: 43$ & $0: 45$ & $0: 47$ \\
\hline Rata-Rata & $0: 43$ & $0: 47$ & $0: 44$ & $0: 45$ & $0: 45$ \\
\hline
\end{tabular}

Pada Tabel 2 terlihat bahwa waktu rata-rata antarkendaraan tertinggi pada halte terjadi pada Halte Unismuh, yaitu 47 menit, dan waktu rata-rata antarkendaraan terendah terjadi pada halte M'TOS, yaitu 43 menit. Waktu rata-rata antarkendaraan secara keseluruhan adalah 45 menit. Degan menggunakan standar World Bank, waktu antarkendaraan ini menunjukkan kinerja yang kurang efektif. Hal ini disebabkan oleh ketersediaan armada dan waktu perjalanan pada sistem operasi terbuka atau lalu lintas campuran, yang menimbulkan waktu tunggu lama bagi pengguna serta mengurangi tingkat potensi keuntungan yang dapat diperoleh.

\section{Waktu Henti Kendaraan}

Data waktu henti bus (dwell time) didapat melalui survei dinamis pada setiap pemberhentian bus. Hasil survei ini disajikan pada Tabel 3.

Pada Tabel 3 terlihat bahwa waktu henti kendaraan tertinggi terjadi pada hari libur (hari Minggu), yaitu 1 menit 28 detik, dan waktu henti terendah terjadi pada hari kerja (hari Senin), yaitu 32 detik, dengan waktu henti rata-rata keseluruhan adalah 54 detik. Secara umum, waktu henti rata-rata kendaraan ini menunjukkan kinerja cukup efektif, dengan kriteria 20 detik hingga 40 detik. Beberapa nilai waktu henti kendaraan yang tinggi disebabkan oleh tidak bebasnya ruang gerak bus di halte, sehingga waktu yang dibutuhkan untuk menaikkan dan menurunkan penumpang lebih lama, dan adanya titik pemeriksaan (check point) yang dilakukan oleh pengawas pada halte tertentu, dan waktu bus menunggu penumpang yang lebih lama pada halte Mall Panakukang. 
Tabel 3 Waktu Henti Kendaraan

\begin{tabular}{|c|c|c|c|c|c|}
\hline $\mathrm{Wa}$ & Henti & Senin & Kamis & Minggu & Rata-Rata \\
\hline \multirow{7}{*}{ Rit } & 1 & $00: 00.19$ & $00: 00.13$ & $00: 00.32$ & $00: 00.21$ \\
\hline & 2 & 00:01.03 & 00:00.04 & $00: 00.45$ & 00:00.37 \\
\hline & 3 & 00:00.47 & 00:00.09 & 00:00.37 & 00:00.31 \\
\hline & 4 & 00:00.15 & 00:02.03 & 00:00.47 & 00:01.02 \\
\hline & 5 & 00:00.30 & $00: 01.05$ & 00:00.32 & 00:00.42 \\
\hline & 6 & 00:00.19 & 00:00.39 & 00:05.32 & 00:02.10 \\
\hline & $\Sigma$ & $00: 00.32$ & $00: 00.42$ & $00: 01.28$ & $00: 00.54$ \\
\hline
\end{tabular}

\section{Waktu Tempuh Setiap Halte}

Waktu tempuh setiap halte didapatkan dari hasil survei dinamis dengan mengukur waktu perjalanan dari halte satu menuju ke halte berikutnya. Rata-rata waktu tempuh setiap halte dapat dilihat pada Tabel 4 .

Tabel 4 Waktu Tempuh Setiap Halte

\begin{tabular}{cccccc}
\hline \multicolumn{2}{c}{ Waktu Tempuh } & Senin & Kamis & Minggu & Rata-Rata \\
\hline \multirow{4}{*}{ Rit } & 1 & $00: 02.20$ & $00: 02.22$ & $00: 01.50$ & $00: 02.11$ \\
& 2 & $00: 02.45$ & $00: 02.22$ & $00: 02.13$ & $00: 02.26$ \\
& 3 & $00: 02.38$ & $00: 02.33$ & $00: 02.40$ & $00: 02.37$ \\
& 4 & $00: 02.42$ & $00: 03.08$ & $00: 03.27$ & $00: 03.05$ \\
& 5 & $00: 03.02$ & $00: 03.25$ & $00: 02.22$ & $00: 02.56$ \\
\multicolumn{2}{l}{ Rata-Rata Waktu Tempuh } & $00: 03.09$ & $00: 03.14$ & $00: 02.36$ & $00: 03.00$ \\
\hline
\end{tabular}

Berdasarkan hasil yang disajikan pada Tabel 4, diperoleh waktu tempuh tertinggi untuk ke setiap halte terjadi pada hari kerja (hari Kamis), yaitu 3 menit 14 detik. Sebaliknya, waktu tempuh terendah terjadi pada hari Minggu, yaitu 2 menit 36 detik. Secara total, waktu tempuh rata-rata ke setiap halte adalah 3 menit. Hasil ini menunjukkan kinerja bus yang efektif. Meningkatnya waktu tempuh ini, umumnya dipengaruhi oleh volume lalu lintas yang terus meningkat, khususnya pada jam sibuk sore.

\section{Waktu Perjalanan}

Waktu perjalanan (travel time) diperoleh dari survei dinamis. Hasil survei waktu perjalanan ini dapat dilihat pada Tabel 5.

Tabel 5 Waktu Perjalanan

\begin{tabular}{cccccc}
\hline & Waktu Perjalanan & Senin & Kamis & Minggu & Rata-Rata \\
\hline \multirow{4}{*}{ Rit } & 1 & $01: 21.44$ & $01: 22.42$ & $01: 04.32$ & $01: 16.19$ \\
& 2 & $01: 28.04$ & $01: 08.39$ & $01: 09.32$ & $01: 15.25$ \\
& 3 & $01: 34.54$ & $01: 27.42$ & $01: 36.08$ & $01: 32.54$ \\
& 4 & $01: 20.40$ & $01: 36.54$ & $01: 46.45$ & $01: 34.46$ \\
& 5 & $01: 46.51$ & $02: 03.43$ & $01: 22.37$ & $01: 44.24$ \\
\multicolumn{2}{l}{ Rata-Rata Waktu Perjalanan } & $00: 42.17$ & $01: 45.19$ & $01: 29.38$ & $01: 39.05$ \\
\hline
\end{tabular}

Waktu perjalanan tertinggi terjadi pada hari kerja (hari Kamis), yaitu 1 jam 45 menit 19 detik, dan yang terendah terjadi pada hari libur (hari Minggu), yaitu 1 jam 29 menit 38 
detik. Waktu perjalanan rata-rata adalah 1 jam 39 menit 5 detik. Waktu perjalanan ini menunjukkan kinerja yang cukup efektif. Waktu perjalanan tersebut dipengaruhi oleh kerapatan atau kepadatan lalu lintas. Bila kerapatan lalu lintas meningkat, kecepatan perjalanan akan berkurang, yang menyebabkan meningkatnya waktu perjalanan.

\section{Kecepatan Perjalanan}

Data kecepatan perjalanan (travel speed) didapat dari hasil survei dinamis berdasarkan jarak tempuh dibagi dengan waktu perjalanan. Data kecepatan perjalanan ini dapat dilihat pada Tabel 6.

Tabel 6 Kecepatan Perjalanan (km/jam)

\begin{tabular}{cccccc}
\hline & Kecepatan Perjalanan & Senin & Kamis & Minggu & Rata-Rata \\
\hline \multirow{4}{*}{ Rit } & 1 & 25 & 24 & 29 & 26 \\
& 2 & 25 & 29 & 29 & 27 \\
& 3 & 22 & 23 & 22 & 23 \\
& 4 & 26 & 23 & 22 & 24 \\
& 5 & 20 & 15 & 24 & 20 \\
\multicolumn{2}{l}{ Rata-Rata Kecepatan Perjalanan } & 22 & 21 & 24 & 22 \\
\hline
\end{tabular}

Rata-rata kecepatan perjalanan tertinggi terjadi pada hari libur (hari Minggu), yaitu $24 \mathrm{~km} / \mathrm{jam}$, dan terendah terjadi pada hari kerja (hari Kamis), yaitu $21 \mathrm{~km} / \mathrm{jam}$. Secara keseluruhan, rata-rata kecepatan perjalanan adalah $22 \mathrm{~km}$ per jam, yang berarti menunjukkan kinerja bus yang efektif.

\section{Waktu Sirkulasi}

Waktu sirkulasi (cycle time) adalah waktu yang ditempuh oleh angkutan umum penumpang dari terminal ujung ke pangkalan yang lain, dan kemudian kembali lagi ke terminal ujung. Data waktu sirkulasi pada studi ini didapat dari survei dinamis, yang dapat dilihat pada Tabel 7.

Tabel 7 Waktu Sirkulasi

\begin{tabular}{cccccc}
\hline & Waktu Sirkulasi & Senin & Kamis & Minggu & Rata-Rata \\
\hline \multirow{2}{*}{ Rit } & 1 & 02.49 .48 & 02.31 .21 & 02.14 .04 & 02.31 .44 \\
& 2 & 02.55 .34 & 03.04 .36 & 03.22 .50 & 03.07 .40 \\
& 3 & 04.28 .22 & 04.55 .58 & 03.20 .53 & 04.15 .04 \\
\hline \multicolumn{2}{l}{ RataRata Waktu Sirkulasi per Hari } & 03.24 .35 & 03.30 .38 & 02.59 .16 & 03.18 .10 \\
\hline
\end{tabular}

Rata-rata waktu sirkulasi tertinggi terjadi pada hari kerja (hari Kamis), yaitu 3 jam 30 menit 38 detik, dan yang terendah terjadi pada hari libur (hari Minggu), yaitu 2 jam 59 menit 16 detik. Rata-rata waktu sirkulasi secara keseluruhan adalah 3 jam 18 menit 10 detik. Waktu sirkulasi ini menunjukkan kinerja yang cukup efektif. Seperti halnya dengan waktu perjalanan, waktu sirkulasi ini juga dipengaruhi oleh kerapatan atau kepadatan lalu lintas. 


\section{Frekuensi Layanan}

Frekuensi layanan adalah banyaknya layanan transportasi yang dilakukan dalam suatu waktu tertentu, misalnya jam (Kementerian Perhubungan, 2012). Frekuensi layanan ini bergantung pada jumlah armada dan waktu antarkendaraan yang direncanakan. Data frekuensi diperoleh dari survei statis pada halte, yang hasilnya dapat dilihat pada Tabel 8 .

Tabel 8 Frekuensi Layanan (bus/jam)

\begin{tabular}{|c|c|c|c|c|c|c|c|c|c|c|c|c|c|c|c|c|c|}
\hline \multirow{2}{*}{ Waktu } & \multicolumn{8}{|c|}{ B. Bandara-Term. Palangga } & \multicolumn{8}{|c|}{ Term. Palangga-B. Bandara } & \multirow{2}{*}{ Rata-Rata } \\
\hline & \multicolumn{4}{|c|}{ Mtos } & \multicolumn{4}{|c|}{ Unismuh } & \multicolumn{4}{|c|}{ Badan Arsip Negara } & \multicolumn{4}{|c|}{ Depan Mtos } & \\
\hline $06.00-6: 59$ & 1 & 1 & 0 & 2 & 1 & 1 & 0 & 1 & 0 & 0 & 0 & 0 & 0 & 0 & 0 & 0 & 0 \\
\hline 07.00-7:59 & 3 & 1 & 2 & 1 & 1 & 1 & 1 & 1 & 1 & 1 & 0 & 0 & 0 & 0 & 0 & 0 & 1 \\
\hline 08.00-8:59 & 2 & 2 & 3 & 2 & 3 & 1 & 3 & 2 & 1 & 1 & 2 & 3 & 1 & 1 & 1 & 1 & 2 \\
\hline 09.00-9:59 & 1 & 2 & 2 & 2 & 1 & 2 & 2 & 2 & 2 & 1 & 1 & 1 & 2 & 1 & 2 & 2 & 2 \\
\hline $10.00-10: 59$ & 3 & 1 & 3 & 2 & 3 & 1 & 2 & 1 & 2 & 2 & 2 & 2 & 1 & 1 & 3 & 1 & 2 \\
\hline $11.00-11: 59$ & 1 & 1 & 2 & 1 & 1 & 2 & 2 & 1 & 1 & 2 & 2 & 1 & 1 & 1 & 0 & 2 & 1 \\
\hline $12.00-12: 59$ & 2 & 1 & 1 & 0 & 1 & 1 & 1 & 0 & 1 & 1 & 2 & 1 & 2 & 2 & 1 & 1 & 1 \\
\hline $13.00-13: 59$ & 0 & 1 & 0 & 2 & 2 & 1 & 1 & 1 & 1 & 1 & 1 & 1 & 1 & 1 & 1 & 1 & 1 \\
\hline $14.00-14: 59$ & 1 & 1 & 1 & 0 & 0 & 0 & 1 & 1 & 1 & 1 & 1 & 1 & 0 & 1 & 2 & 1 & 1 \\
\hline $15.00-15: 59$ & 2 & 1 & 1 & 1 & 1 & 1 & 1 & 1 & 1 & 1 & 0 & 1 & 1 & 1 & 1 & 1 & 1 \\
\hline $16.00-16: 59$ & 0 & 2 & 1 & 1 & 2 & 0 & 0 & 1 & 3 & 1 & 2 & 1 & 1 & 1 & 0 & 0 & 1 \\
\hline $17.00-17: 59$ & 1 & 1 & 0 & 1 & 0 & 2 & 0 & 1 & 2 & 1 & 0 & 2 & 3 & 1 & 3 & 3 & 1 \\
\hline $18.00-18: 59$ & 1 & 0 & 0 & 0 & 1 & 1 & 0 & 1 & 1 & 1 & 0 & 0 & 1 & 1 & 0 & 2 & 1 \\
\hline $19.00-19: 59$ & 0 & 0 & 0 & 0 & 1 & 0 & 0 & 0 & 0 & 0 & 0 & 1 & 2 & 0 & 0 & 1 & 0 \\
\hline $20.00-21: 00$ & 0 & 0 & 0 & 0 & 0 & 0 & 0 & 0 & 0 & 0 & 0 & 0 & 1 & 0 & 0 & 0 & 0 \\
\hline $\begin{array}{l}\text { Rata-Rata } \\
\text { Frekuensi }\end{array}$ & 1 & 1 & 1 & 1 & 1 & 1 & 1 & 1 & 1 & 1 & 1 & 1 & 1 & 1 & 1 & 1 & 1 \\
\hline
\end{tabular}

Dari Tabel 8 diketahui bahwa frekuensi tertinggi terjadi antara jam 08:00 sampai jam 10:59, yaitu sebesar 2 bus/jam, dan yang terendah terjadi antara jam 06:00 sampai 06:59 dan jam 19:00 sampai 21:00, karena tidak terdapat bus yang melayani pada periode waktu tersebut (hasil perhitungan kurang dari 0,4 dibulatkan menjadi 0,0). Secara umum, rata-rata frekuensi layanan adalah 1 bus/jam. Frekuensi layanan bus ini menunjukkan kinerja yang kurang efektif.

\section{Jarak Antarhalte}

Jarak antarhalte didapat melalui survei lapangan berdasarkan tata guna lahan. Data jarak antarhalte ini disajikan pada Tabel 9.

Jarak antarhalte pada ruas jalan yang dilalui oleh bus Trans Mamminasata pada Koridor 3 tidak memenuhi standar BRT Indonesia, yaitu antara $300 \mathrm{~m}$ hingga $800 \mathrm{~m}$. Karena itu, jarak antarhalte pada Koridor 3 menunjukkan kinerja kurang efektif. Kurang baiknya jarak antarhalte menyebabkan kurangnya permintaan (demand) pada kawasan yang berpotensi menggunakan jasa angkutan umum ditinjau dari tata guna lahan suatu kawasan.

\section{Tingkat Ketersediaan Armada}

Tingkat ketersediaan armada (availability) diperoleh melalui survei statis. Hasil survei ini selengkapnya disajikan pada Tabel 10.

Rata-rata tingkat ketersediaan armada yang tertinggi terdapat di Halte M'TOS, yaitu sebesar 78\%, sedangkan yang terendah terdapat di Halte Universitas Muhammadiyah 
dan Badan Arsip Negara, yaitu 65\%. Rata-rata tingkat ketersediaan armada bus adalah $70 \%$, yang menunjukkan kinerja yang efektif. Namun, perlu dicatat pula bahwa tingkat ketersediaan bus yang melebihi jumlah permintaan dapat mengurangi pendapatan yang diterima, sehingga pada akhirnya dapat menyebabkan kerugian bagi penyedia jasa.

Tabel 9 Jarak Antarhalte

\begin{tabular}{|c|c|c|c|c|}
\hline \multirow{2}{*}{ Ruas Jalan } & \multirow{2}{*}{ Kawasan } & \multicolumn{2}{|c|}{ Jarak Rata-Rata Halte $\left(\mathrm{m}^{\prime}\right)$} & \multirow{2}{*}{$\begin{array}{l}\text { Standar } \\
\text { (m) }\end{array}$} \\
\hline & & Arah Bandara & Arah T. Palangga & \\
\hline Gowa Raya & Permukiman sedang & 2300 & 1800 & $300-400$ \\
\hline Sultan Alauddin & Permukiman sedang, pendidikan & 1150 & 600 & $300-500$ \\
\hline A.P. Pettarani & $\begin{array}{l}\text { Perkantoran, perdangan dan jasa, } \\
\text { permukiman tinggi sedang } \\
\text { campuran }\end{array}$ & 1017 & 1000 & $300-400$ \\
\hline Jalan Urip Sumoharjo & $\begin{array}{l}\text { Campuran, pendidikan, } \\
\text { perkantoran, permukiman tinggi } \\
\text { dan sedang } \\
\text { pendidikan, campuran, sarana } \\
\text { kesehatan }\end{array}$ & 1200 & 840 & $300-400$ \\
\hline \multirow[t]{2}{*}{ Perintis Kemerdekaan } & $\begin{array}{l}\text { Perkantoran, perdangan dan jasa, } \\
\text { serta Permukiman tinggi dan } \\
\text { sedang }\end{array}$ & 907 & 694 & $300-400$ \\
\hline & Jarak Rata-Rata (m) & 1315 & 978 & $300-800$ \\
\hline
\end{tabular}

Tabel 10 Tingkat Ketersediaan Bus

\begin{tabular}{lrrccc}
\hline \multicolumn{1}{c}{ Hari, Tanggal } & Mtos & Unismuh & Badan Arsip & Depan Mtos & Rata-Rata \\
\hline Sabtu & $100 \%$ & $100 \%$ & $70 \%$ & $70 \%$ & $85 \%$ \\
Minggu & $60 \%$ & $50 \%$ & $50 \%$ & $60 \%$ & $55 \%$ \\
Rabu & $80 \%$ & $70 \%$ & $70 \%$ & $60 \%$ & $70 \%$ \\
Jumat & $70 \%$ & $70 \%$ & $70 \%$ & $70 \%$ & $70 \%$ \\
\hline Tingkat Ketersediaan Rata-Rata & $78 \%$ & $73 \%$ & $65 \%$ & $65 \%$ & $70 \%$ \\
\hline
\end{tabular}

\section{Waktu Pelayanan}

Waktu pelayanan adalah waktu yang dibutuhkan untuk melayani penumpang. Waktu pelayanan pada studi ini didapat melalui survei statis, yang hasilnya dapat dilihat pada Tabel 11.

Tabel 11 Waktu Pelayanan

\begin{tabular}{lrcccc}
\hline \multicolumn{1}{c}{ Waktu Pelayanan } & Mtos & Unismuh & Badan Arsip & Depan Mtos & Rata-Rata \\
\hline Hari kerja (Rabu dan Jumat) & 12 & 12 & 13 & 11 & 12 \\
Hari libur (Sabtu dan Minggu) & 13 & 14 & 13 & 14 & 13 \\
\hline Waktu Pelayanan Rata-Rata & 12 & 13 & 13 & 13 & 13 \\
\hline
\end{tabular}

Rata-rata waktu pelayanan tertinggi terjadi pada hari libur, yaitu 13 jam, dan yang terendah terjadi pada hari kerja, yaitu 12 jam. Secara keseluruhan rata-rata waktu pelayanan adalah 13 jam. Dengan menggunakan waktu pelayanan ini, bus Trans Mamminasata di Koridor 3 mempunyai kinerja yang efektif. 


\section{Umur Kendaraan}

Data umur kendaraan didapat dari hasil survei berdasarkan masa berlaku pelat nomor kendaraan. Dari survei yang dilakukan diperoleh umur rata-rata kendaraan adalah 4 tahun, yang berarti kinerja bus Trans Mamminasata di Koridor 3 adalah efektif.

\section{Operating Ratio}

Rata-rata penumpang per bus sebanyak 98 orang dengan tarif setiap penumpang Rp4.500,00. Pendapatan setiap bus dan operating ratio dapat dilihat pada Tabel 12.

Tabel 12 Operating Ratio

\begin{tabular}{lc}
\hline Indikator & Jumlah \\
\hline Rata-Rata Jumlah Penumpang & 98 \\
Tarif Angkutan & $\mathrm{Rp} 4.500,00$ \\
Pendapatan Setiap Bus & $\mathrm{Rp} 441.000,00$ \\
Biaya Operasional Kendaraan & $\mathrm{Rp} 550.000,00$ \\
\hline Operating Ratio & 0,80 \\
\hline
\end{tabular}

Nilai operating ratio layanan bus Trans Mamminasata pada kajian ini adalah 0,80:1. Hasil ini menunjukkan kinerja bus yang kurang efektif, yang disebabkan oleh perbandingan jumlah penumpang dengan biaya operasional kendaraan tidak seimbang, sehingga terjadi defisit.

\section{Kapasitas}

Jumlah armada dan kapasitas moda yang dibutuhkan dianalisis berdasarkan waktu sirkulasi dan waktu antara kendaraan, yang diperoleh dari hasil survei. Kebutuhan jumlah armada adalah sebanyak 5 unit dengan kapasitas muat armada sebesar 79 penumpang. Data rata-rata jumlah armada yang didapat dari survei statis adalah 7 unit dengan kapasitas ratarata 100 penumpang. Karena itu, dari jumlah armada yang ada dan kapasitas bus yang beroperasi, kinerja bus di Koridor 3 cukup efektif.

\section{KESIMPULAN}

Kebijakan transportasi publik perkotaan yang efektif adalah kebijakan yang dapat menyelenggarakan kegiatan pelayanan transportasi perkotaan yang efektif dan efisien. Kapasitas pelayanan bus Trans Mamminasata pada Koridor 3 Kawasan Mamminasata berlebihan, sehingga menimbulkan pemborosan. Kapasitas transportasi yang ada tidak dimanfaatkan sehingga menunjukkan kinerja belum efektif.

Ketepatan kualitas pelayanan berdasarkan kecepatan perjalanan, tingkat ketersediaan armada, umur kendaraan, keselamatan atau keamanan, dan kenyamanan sudah menunjukkan kinerja yang efektif. Sedangkan faktor muat, frekuensi, jarak antarhalte, keteraturan, ketertiban, komprehensif, bertanggung jawab, aksesbilitas, keandalan, dan kemudahan informasi belum menunjukkan kinerja yang efektif. 
Dari segi ketepatan waktu, berdasarkan waktu tempuh setiap halte dan waktu operasi pelayanan, menunjukkan kinerja yang efektif, sedangkan waktu tunggu, waktu antarkendaraan, waktu henti kendaraan, waktu perjalanan, dan waktu sirkulasi belum menunjukkan kinerja yang efektif. Sementara itu, dari segi biaya, layanan bus Trans Mamminasata menunjukkan kinerja yang efektif, walaupun operation ratio belum menunjukkan kinerja yang efektif.

\section{DAFTAR PUSTAKA}

Abubakar, I. 1996. Menuju Lalu Lintas dan Angkutan Jalan yang Tertib. Direktorat Jenderal Perhubungan Darat. Jakarta.

Armstrong-Wright, A. dan Thiriez, S. 1987. Bus Service: Reducing Cost and Raising Standards. The International Bank for Reconstruction and Development, The World Bank, Washington, DC.

Badan Pusat Statistik. 2017. Sulawesi Selatan dalam Angka. Makassar.

Kementerian Perhubungan. 2012. Studi Penyusunan Konsep Standarisasi Sarana dan Prasarana Bus Rapid Trasnsit (BRT) di Kota Indonesia. Badan Penelitian dan Pengembangan Perhubungan. Jakarta.

Sugiyono, P.D. 2014. Cara Mudah Menyusun Skripsi, Tesis, dan Disertasi. Bandung: CV Alfabeta.

Warpani, S. 2002. Pengelolaan Lalu Lintas dan Angkutan Jalan. Bandung: Penerbit Institut Teknologi Bandung. 